\title{
The Comparison of Forensic-Psychiatric Traits between Female and Male Perpetrators of Murder or Attempted Murder
}

\author{
L. Mužinić Masle, M. Goreta and V. Jukić \\ Psychiatric Hospital Vrapče, Zagreb, Croatia
}

\section{A B S T R A C T}

The aim of this investigation was to define more clearly specific forensic-psychiatric characteristics of female murder or attempted murder perpetrators. The retrospective method applied was based on the comparison of the data from forensic-psychiatric assessments carried out in the Center for Forensic Psychiatry, Psychiatric Hospital Vrapče, Zagreb, from 1983 to 1997 (including 70 female and 70 male subjects - who committed murder or attempted murder). Compared with men, female offenders were most often in some way emotionally related to their victims, and they were more often victimized themselves before committing the crime. In men alcoholism was a more significant circumstantial factor in the assessment of their accountability. Psychiatric security measures were more often given to male offenders. The intensity of aggression was lower in females than in males. This investigation reveals that there are some sex specific forensic-psychiatric traits of murder or attempted murder perpetrators. The obtained results could be of help in everyday forensic-psychiatric practice, both in assessments and treatment.

\section{Introduction}

There is not much literature on female offenders, particularly of those who committed murder or attempted murder. Criminology rarely refers to women, as it is mainly concentrated on male behavior ${ }^{1}$. According to the conventional opinion criminal conduct is rather typical of men. Such a view is not only due to prejudices related to social gender roles, but it is also grounded on the fact that in all historical periods and in all countries of the world men commit more crimes than women, especially violent acts $^{2}$. There are, however, some crime investigations which

Received for publication October 11, 1999. 
indicate a much higher female crime rate $^{3}$. It is quite interesting that women rarely murder other women, i.e. they almost exclusively kill men, while men most frequently kill other men ${ }^{4}$.

In such relatively scarce literature data on this topic we can still find a number of controversial views related to:

- nature and seriousness of psychopathology of female offenders and the degree of diminished accountability based on that psychopathology;

- intensity and nature of female aggression and its impact on the severeness of the committed crime within the same categories of crimes;

- disposition for a later criminal behavior;

- specific emotional, family or other relationship between the offender and the victim;

- alcohol as a contributing factor in female delinquency;

- dangerousness for other people.

The present paper is aimed at presenting forensic psychiatry specific traits of female offenders who committed murder or attempted murder.

\section{Subjects and Methods}

The investigation included 70 females and 70 males who had committed murder or attempted murder. The retrospective method applied was based on the comparison of data from forensic psychiatric assessments done from 1983 to 1997 at the Center for Forensic Psychiatry of the Psychiatric Hospital Vrapče.

As women are generally fewer in criminal population than men, and, consequently, in the category of perpetrators of the most serious crimes against life and body (murder and attempted murder) as well, the authors first selected the mentioned number of expert opinions con- cerning female delinquents, and then the male sample was formed by separating each Nth expert opinion from the same period of time ( $\mathrm{N}$ is a coefficient obtained by dividing the total number of the "male« expert opinions with the number of "female" opinions for the same period of time).

The research instrument consisted of the modified standardized questionnaire (developed by the working group for documentation in forensic psychiatry at the Munich Psychiatric Hospital), which contains all relevant data: demographic (sex, age, marital status, educational level, occupation etc.), criminological (type and instrument of crime, relationship between perpetrator and victim etc.) and specific forensic psychiatric data (diagnosis according to ICD-10, assessment of accountability and risk behavior, security recommendations etc. $)^{5-7}$. The questionnaire was filled up with the data from forensic psychiatric expert opinions composed in the Center for Forensic Psychiatry of the Psychiatric Hospital Vrapče, for all the subjects, both male and female.

For the comparison of proportion between two independent groups we used the analysis of contingency tables with the calculation of Chi-square, with Pearsons $\mathrm{R}$ correlation coefficient. This method was used for 22 tables where we had one variable defined with two categories which excluded one another. Statistical significance was established at the 5\% level. Statistical analysis was performed by the SPSS statistical software.

\section{Results}

\section{Crime}

In the observed group women committed 39 homicides and 31 attempted homicides, while men committed 48 homicides and 22 attempted homicides, but the obtained correlation is not statistically sig- 
nificant. A secondary charge was recorded in 9 male cases (out of which 8 attempted murders and 1 robbery), while no secondary charges were recorded for female offenders. Male perpetrators committed a criminal act most often in an open space $(34.3 \%)$; only $7.1 \%$ of female perpetrators killed in an open space. Most of the women committed a crime in the shared apartment (57.1\%), which was the scene of tragedy in only $25.7 \%$ of male perpetrators. The most frequent instruments of male perpetrators were firearms (44.3\%), followed by knives/cutting instruments $(31.4 \%)$. The majority of females used knives/cutting instruments (68.6\%). The results show a statistically significant, though weak correlation.

\section{Typology of offenders}

Serial offenses were recorded in $25.7 \%$ male cases, and only in $4.3 \%$ female cases. There is a moderate statistically significant correlation between these results. In contrast to males, previous violations of law were not recorded for the majority of female offenders (Table 1). The difference is statistically significant between the two groups according to the previous criminal record $\left({ }^{2}=26.72\right.$, df $=$ $4, \mathrm{p}=0.000$ ). Male offenders committed more felonies (murder, attempted murder, rape) than females, as shown by a moderate statistically significant correlation. Also, more males had previous crim- inal record (54.3\%) than females (only $18.6 \%$ ), as confirmed by a moderate statistically significant correlation.

\section{Victimology}

The majority of victims of male offenders belonged to the group of acquaintances/friends $(30 \%)$, and only in $8 \%$ of the cases to spouses. In female offenses, husbands were victims in $33 \%$ of cases, and common-law husbands in $10 \%$ of cases. The obtained correlation is quite high and statistically significant. Further analysis of the perpetrator-victim relationship indicated that the majority of female offenders had been in a mutual stable relationship. Short-term, one-sided and non-existent relationships with the victim were more frequent in males (Table 2 ). The difference is statistically significant between the two groups according to the offender/victim relationship ( ${ }^{2}=$ 16.54 , df $=3, \mathrm{p}=0.001$ ). Active or conscious provocation of the criminal act was recorded in $60 \%$ of female offenders and in $35.7 \%$ of male offenders. An insignificant victim's contribution to the crime was recorded in $20 \%$ of female offenders and in $28.6 \%$ of male offenders. During the committment of the crime, female offenders defend themselves, children or other close persons from psychological or physical abuse much more often than male offenders do (Table 3 ). The difference is statistically significant ( ${ }^{2}=29.07, \mathrm{df}=4$,

TABLE 1

PREVIOUS CRIMINAL RECORD

\begin{tabular}{lrrrc}
\hline & \multicolumn{2}{c}{ Males } & \multicolumn{2}{c}{ Females } \\
\cline { 2 - 5 } Number of previous offenses & $\mathrm{n}$ & $\%$ & 57 & $\% 1.4$ \\
\hline No previous record & 30 & 42.9 & 7 & 10.0 \\
1 offense & 8 & 11.4 & 5 & 7.1 \\
$2-5$ offenses & 22 & 31.4 & 1 & 1.4 \\
$6-10$ offenses & 6 & 8.6 & - & - \\
More than 10 offenses & 4 & 5.7 & 70 & 100.0 \\
\hline Total & 70 & 100.0 & & \\
\hline
\end{tabular}


TABLE 2

OFFENDER/VICTIM RELATIONSHIP

\begin{tabular}{lrrrr}
\hline & \multicolumn{2}{c}{ Males } & \multicolumn{2}{c}{ Females } \\
\cline { 2 - 5 } Type of relationship & $\mathrm{n}$ & $\%$ & $\mathrm{n}$ & $\%$ \\
\hline No relationship & 9 & 12.9 & 2 & 2.9 \\
One-sided relationship & 11 & 15.7 & 7 & 10.0 \\
Mutual short relationship & 22 & 31.4 & 10 & 14.3 \\
Mutual stable relationship & 28 & 40.0 & 51 & 72.9 \\
\hline Total & 70 & 100.0 & 70 & 100.0 \\
\hline
\end{tabular}

TABLE 3

DEFENSE TEMPORE CRIMINIS FROM PHYSICAL AND PSYCHOLOGICAL ABUSE

\begin{tabular}{lrrrr}
\hline & \multicolumn{2}{c}{ Males } & \multicolumn{2}{c}{ Females } \\
\cline { 2 - 5 } Defense & $\mathrm{n}$ & \multicolumn{1}{c}{ n } & $\%$ \\
\hline No & 58 & 82.9 & 28 & 40.0 \\
Self-defense & 8 & 11.4 & 30 & 42.9 \\
Defense of children & 2 & 2.9 & 3 & 4.3 \\
Defense of other close persons & 2 & 2.9 & 4 & 5.7 \\
Combination & - & - & 5 & 7.1 \\
\hline Total & 70 & 100.0 & 70 & 100.0 \\
\hline
\end{tabular}

$\mathrm{p}=0.000$ ). Women were (themselves or along with their children and other close persons) previously abused by the victim in $70 \%$ of the cases, while for male offenders this category amounts to $5.7 \%$. The obtained correlation is highly statistically significant.

\section{Social factors}

The highest number of male offenders belonged to 21-25 age group (20\%), in comparison to females, the highest number of whom were found in 31-35 age group. There is a moderate statistically significant correlation between marital status and sex. Male offenders were for the most part either single $(47.1 \%)$ or married (37.1\%), while most of the female offenders were married $(71.4 \%)$. The majority of male offenders (34.3\%) had secondary education, while females in most cases had not finished elementary school $(38.6 \%)$. University education was not recorded in male offenders, while $5.7 \%$ of female offenders graduated from college. In both groups of subjects we found several straining factors in the psychosocial situation of the family (frequent severe conflicts, strained material circumstances, poor emotional relationship, inconsistent upbringing) and in the offender's childhood or adolescence (marked aggressiveness, excessive adaptability, developmental disturbances, emotional disturbances, educational problems), and the difference between the sexes is not statistically significant.

\section{Psychiatric case history}

Previous suicide attempts were recorded in 17 female and 6 male offenders. Males were more often hospitalized for 
alcohol abuse treatment or schizophrenia, and females for suicidal attempts and schizophrenia. The results are not statistically significant. The most frequent psychiatric diagnosis in both sexes (made during the expertise) was personality disorder, F60-F69 (54.3\% males and $52.9 \%$ females), followed by F20-F29 disorders (18.6\% males and $17.1 \%$ females). A higher difference between the sexes was found in F40-F43 category (11.4\% females and $1.4 \%$ males), while more males were found in category F10-F19 (10.0\%), than females $(4.3 \%)$.

Paranoid personality disorder was found in 10 male and 4 female offenders, schizoid disorder in 4 male and 3 female offenders, dissocial disorder in 10 male and 3 female offenders, emotional instability in 2 male and 2 female offenders, histrionic disorder in 2 male and 2 female offenders, narcissistic disorder in 3 male and 3 female offenders, "other personality disorders « in 24 male and 24 female offenders.

\section{Forensic psychiatric analysis of criminal acts}

A higher number of female perpetrators $(61.4 \%)$ were not under the influence of psychotropic substances than males $(38.6 \%)$ at the time of the crime commit- tment. A higher number of males were intoxicated (52.9\%) than females $(30.0 \%)$ at the time of the criminal act.

A serious conflict situation was recorded for $48.6 \%$ females and for $28.6 \%$ males, with a weak but statistically significant correlation. There are no statistically significant differences between the sexes in diagnosed mental illness, temporary mental illness or temporary mental disorder. The highest number of offenders of both sexes were judged as being in a state of essentially diminished accountability $^{(1)}(42.9 \%$ males and $48.6 \%$ females), while four male and one female offenders were found fully responsible. The correlation is not statistically significant.

\section{Legal criteria and recommendations}

A favorable or mostly favorable prognosis was found in $81.4 \%$ offenders, while $60 \%$ of male offenders had unfavorable prognosis. The obtained correlation is highly statistically significant. More females did not receive compulsory treatment in a secure medical facility $(65.7 \%)$. There is a difference between the sexes in received compulsory treatment for alcohol abuse in a medical institution by $25.7 \%$ males and $7.1 \%$ females.

(1) Guilt, according to the Criminal Law of Croatia (which was in effect at the time of this research), consists of conceit and negligence. Accountability and guilt are here essential components of criminal responsibility. The definition of accountability is negative: "A subject who during the criminal act could not understand the meaning of this action, or could not control his action due to permanent or temporary mental illness, temporary mental disorder, or retarded mental development is not accountable. « If his abilities were eseentially reduced, the accountability is also essentially reduced. Disorders of psychic functions in cases of diminished responsibility are of the same nature as in cases of lack of criminal responsibility, but of a smaller intensity. Thus, when criminal responsibility is essentially diminished (owing to existing abnormal states), the person in question is capable of controlling his actions, but the ability to do so is essentially reduced. For the diagnosis of essentially diminished criminal responsibility, the psychic capabilities of the perpetrator must have been essentially reduced. This means that not just any reduction of such capabilities is taken into account, but only an essential reduction. The reduction of the person's ability to comprehend the significance of his actions and to control his behavior is considered essential if the intensity of the disorder is considerable and if it had a decisive effect on the defendant at the moment when the crime was committed. Nonsignificant reductions of psychic capabilities cannot be taken as grounds for essentially diminished responsibility. In this case, the perpetrator is considered as responsible, while the established degree of reduction of his mental capabilities may be taken into account in assessing the degree of his criminal responsibility. 


\section{Discussion}

Statistical significance of a higher incidence in male offenders of secondary charges, serial crimes, previous offenses, conducts and records, leads to the conclusion that the intensity of aggression in female offenders who committed murder or attempted murder was lower than in the same category of male offenders. The fact that for the majority of female offenders it was the first criminal offense indicates the existence of specific circumstances which led to the crime. The victim of $33 \%$ of female offenders was husband, while the victim of $30 \%$ of male offenders was an acquaintance or friend. A non-existent relationship with the victim was more frequent in male offenders. It can be said that, in comparison to males, the victims of female offenders convicted of murder or attempted murder were more frequently family members or other emotionally close persons. Consequently, the most frequent place of crime of female offenders was home while that of male offenders was an outdoor space.

Defensive behavior tempore criminis was more frequently recorded in females, as well as different kinds of abuse preceding the violent act. Women were more often victimized than men and their previous role of a victim represented a major criminogenic factor in their criminal conduct. At the time of the crime commitment the majority of victims of female offenders provoked the offender's aggressive response. Konstatinović-Vilić ${ }^{2}$ thinks that the motive of the majority of female murderers is to defend themselves from physical and psychological abuse of their husbands or common-law husbands with which they have been trying to cope for years. The main goal of the murder is to destroy the tyrant who has abused the family.

The choice of murder instrument was caused by the circumstances at the time of the committed murder. Most frequently, it was the first object at hand of the female offender, e.g. a kitchen knife or other cutting instrument. Similar results are found elsewhere ${ }^{8}$.

The relationships in the primary family of the offender play a major role in criminology. In both groups the majority of offenders had a record of several psychosocial straining factors within family or from other childhood and adolescent experiences. Sila ${ }^{7}$ found a high presence of negative family relationships in offenders convicted of murder and concluded that disturbed family relations, among other factors, should be the key for understanding the formation of murderer's personality ${ }^{9}$.

The level of education was rather low in both groups. A number of other studies $^{9-11}$ indicate bad material circumstances of offenders as a logical consequence of low education level and unemployment.

Marital status is often included among the variables of crime investigations to define the degree of protective strength of marriage in terms of delinquency in general, including homicides. Some studies ${ }^{11}$ indicate that family life should be perceived as a sort of prophylactic protection from delinquency. Such an opinion is explained by the views that family life preserves balance and restrains adventurism of the individual, diminishing in this way his/her exposure to risks. However, our results show that the married status of investigated female offenders contributed to their criminal conduct. Similarly, some authors ${ }^{12,13}$ state that marriage represents a major stabilizing factor of male behavior, while it has unfavorable effect on women by increasing their delinquency. In terms of this, it has been observed also that married women usually commit felonies. 
A higher number of male offenders were intoxicated when committing the crime, which indicates that the intoxicated state occurs more frequently among circumstantial factors in assessing accountability of male perpetrators of murder or attempted murder. Alcohol consumption is still traditionally regarded as a rather male privilege. As a result of the different points of view of the two sexes regarding drinking, alcoholism is rarely found as a direct criminogenic factor in cases of female offenders. The investigation of homicides in Croatia ${ }^{14}$ carried out in 1964 shows that only $5.8 \%$ of women committed murder while intoxicated.

The diagnoses in the majority of offenders in both sex groups were personality disorders and, in the second place, schizophrenia. Many studies ${ }^{15,16}$ indicate a high percentage of mental disorders ${ }^{(2)}$ in female offenders, but the majority of them fall within the category of personality disorder and are not mentally ill. It can be said that the incidence of mental disorders is rather high, in contrast to a low incidence of mental diseases.

As the highest number of offenders in both groups were judged as being in the state of essentially diminished accountability, the two groups could not be differentiated in terms of the severity of psychopathological states which could lead to essentially diminished accountability.

Delinquency prognosis differs between the sexes, as a higher number of male offenders have unfavorable prognosis. Analyzing murders of partners from close relationship, Kovčo ${ }^{17}$ finds a difference between the sexes in sentencing, as male offenders are usually sentenced to 10-20 years of imprisonment, while fe- male offenders get 3 years. The information about milder sentences to women can be found in Barnard's study ${ }^{18}$. Contrary to male murderers, a female murderer is rarely sentenced to death. The question arises whether this fact proves that women are "weaker sex" and therefore should be treated with more compassion, which is certainly in opposition to the objectives of feminist demands ${ }^{2}$. However, it may not be the privilege of female murderers, but a consequence of a large number of borderline cases with infanticide, the existence of a series of extenuating circumstances, and the fact that female murderers are not recidivists ${ }^{2}$. In assessing the criminal responsibility a role can be played also by broader socio-psychological factors - from a more protective attitude of the judges towards women with children, or those who were »forced « to kill by the victim's behavior. It can be said that risk factors for females are more determined by circumstances and interpersonal relationships in contrast to male offenders whose risk factors are more based on permanent personality traits. Although for the majority of offenders psychiatric security measures were not required, male offenders more frequently underwent compulsory alcohol abuse treatment, which indicates that within the same diagnostic categories psychiatric security measures are more often required for males who committed murder or attempted murder than for females.

The results of our research are similar to the results Kellerman ${ }^{19}$ obtained in his study covering the period from 1976 to 1987. The author used the data of Federal Bureau of Investigation Uniform Crime Reports. The results show that, al-

(2) According to the ICD-10 mental disorder is not an exact notion, but is used to denote the existence of clinically distinguishable group of symptoms or behaviors, connected mostly with the suffering of and the effect on an individual's functioning. A social deviation or a conflict alone, without dysfunction of an individual, should not be included into mental disorders as defined here. 
though women make more than a half of population in the USA, they committed only $14.7 \%$ of murders in the period of the study. Unlike men, $80 \%$ of whom killed a person with whom they had no intimate relationship, or strangers, or persons with whom their relationship was undefined, $60 \%$ of women murderers killed their husbands or a member of their family.

It can be concluded that there are some specific forensic psychiatric charac- teristics of female offenders who committed murder or attempted murder (the victim is emotionally close to the offender, the offender is often victimized prior to the crime, alcohol rarely appears among circumstantial factors, women have better rehabilitation prognosis and security measures are rarely pronounced to them). The presented results can be of help in everyday forensic psychiatry practice, both in the field of expertise and in forensic psychiatric treatment.

\section{R E F E R E N C E S}

1. SINGER, M.: Criminology. In Croat. (Nakladni zavod Globus, Zagreb, 1994). — 2. KONSTATINOVIĆ VILIĆ, S.: Female homicides. In Serbian. (Gradina, Niš, 1986). - 3. D’ORBAN, P. T., Female homicides. In: GUNN, J., P. TAYLOR (Eds.): Forensic psychiatry, clinical, legal and ethical issues. (Butterworth-Heinaman, London, 1993). - 4. WILBANSK, W., International Journal of Womens Studies, 6 (1984) 302. 5. NEDOPIL, N., Quantifizierende Dokumentation in Bereich der forensischen Psychiatrie. In: KURY, H. (Ed.): Ausgewahlte Fragen und Probleme forensischer Begutachtung. (C. Heymanns Verlag, Köln, 1987). - 6. NEDOPIL, N., Mschr. Krim., 71 (1988) 117. - 7. ROSLER, M., R. D. STIEGLITZ, Monatsschrift für Kriminologie und Strafrechtsreform, 4 (1996) 223. - 8. BLOCK, C. R., A. CHRISTAKOS, Crime and Delinquency, 41 (1995) 496. - 9. SILA, A., R. TURČIN: Medical expertise in the courts of law. In Croat. (Centar za forenzičku psihijatriju Psihijatrijske bolnice Vrapče, Zagreb, 1976). — 10. VUČKOVIĆ,

\begin{abstract}
V.: Medical expertise in the courts of law. In Croat. (Centar za forenzičku psihijatriju Psihijatrijske bolnice Vrapče, Zagreb, 1976). — 11. MLAĐENOVIĆ, K. R.: Social and individual characteristics of the homicidal population in Bosnia and Herzegovina. In Croat. (Godišnjak Pravnog fakulteta u Sarajevu, Sarajevo, 1973). - 12. ELIOT, M.: Crime in modern society. In Croat. (Veselin Masleša, Sarajevo, 1962). 13. LOMBROSO, C., G. FERRERO, Das Weib als Verbrecherin und Prostituirte. In: KONSTATINOVIĆ VILIĆ, S. (Ed.): Female homicides. In Serbian. (Gradina, Niš, 1986). - 14. MARKOVIĆ, T., JRKKP, 3 (1964) 346. - 15. DANIEL, A. E., P. W. HARRIS, Bull. Am. Acad. Psychiatry Law, 10 (1982) 261. — 16. DANIEL, A. E., J. H. KASHANI, Psychiatry Ann., 5 (1983). - 17. KOVČO, I.: Hrvatski ljetopis za kazneno pravo i praksu, 3 (1995) 111. - 18. BARNARD, G. W., M. I. VERA, G. NEWMAN, Bulletin of the APPL, 10 (1982) 271. - 19. KELLERMAN, A. L., The Journal of Trauma, 33 (1992) 1.
\end{abstract}

\section{Mužić Masle}

Psychiatric Hospital Vrapče, Bolnička 32, 10090 Zagreb, Croatia

\section{USPOREDBA FORENZIČKO-PSIHIJATRIJSKIH OBILJEŽJA ŽENSKIH I MUŠKIH POČINITELJA KAZNENIH DJELA UBOJSTVA I POKUŠAJA UBOJSTVA}

\section{S A Ž E T A K}

Cilj istraživanja bio je jasnije definiranje specifičnih ženskih forenzičko-psihijatrijskih obilježja počinitelja kaznenih djela ubojstva i pokušaja ubojstva. Primijenjena je retrospektivna metoda koja se temelji na komparaciji podataka sadržanih u forenzi- 
čko-psihijatrijskim ekspertizama izrađenim od 1983. do 1997. godine (koje se odnose na 70 ženskih i 70 muških ispitanika - počinitelja kaznenih djela ubojstva i pokušaja ubojstva). Kod ženskih počinitelja žrtva je najčešće osoba s kojom je ona u nekoj vrsti emotivne veze, žene su učestalije bile u poziciji žrtve prije počinjenja djela. Alkoholiziranost kod muškaraca značajniji je konstelativni faktor u procjeni uračunljivosti. Psihijatrijske mjere sigurnosti češće se izriču muškim počiniteljima. Intenzitet agresije u skupini ženskih počinitelja manji je nego kod muških počinitelja. Istraživanjem se pokazalo da postoje specifična ženska forenzičko-psihijatrijska obilježja počinitelja kaznenih djela ubojstva i pokušaja ubojstva. Rezultati bi mogli pomoći u svakodnevnoj praksi forenzičko-psihijatrijskog rada, kako na području vještačenja, tako i na području forenzičko-psihijatrijskog liječenja. 